\title{
Pengembangan Instrumen Pengukuran Kompleksitas Soal Kontekstual Matematika
}

\author{
Chatarina Citra Susilowati ${ }^{1}$, Veronica Yeshinta Komalasari ${ }^{2}$ \\ ${ }^{1,2}$ Mahasiswa S1 Pendidikan Matematika FKIP Universitas Sanata Dharma
}

\begin{abstract}
Contextual complexity of mathematical problems that exist in Indonesia until this time does not have current measuring instruments. Contextual problem should be measured to be correct in its use, such as the achievement of competence and estimated time to work. This research aims to develop measuring instrument contextual complexity of mathematical problems. The method which being used is research design and development. The research subjects are $8^{\text {th }}$ prospective math teachers of seventh semester and seven $\mathrm{X}$ graders. The instruments has been validated by experts to obtain feedback in perfecting. The trial begins by asking a few prospective math teacher of seventh semester to fill contextual complexity instrument of mathematical problems, then ask the seven $\mathrm{X}$ graders to solve the given problems. From the results test in the use of the instrument on the subject, the research results that the instrument can be properly used and give good measurement on the modeling mathematical ability for mathematics education students. The results show that it has successfully designed and arranged contextual complexity instrument of mathematical problems.
\end{abstract}

Keywords: Instrument Development; Question's Complexity; Contextual

\begin{abstract}
Abstrak
Kompleksitas soal-soal kontekstual matematika yang ada di Indonesia sampai saat ini belum ada instrumen pengukurannya. Soal-soal kontekstual perlu dilakukan pengukuran supaya tepat dalam penggunaannya, seperti ketercapaian kompetensi dan memperkirakan waktu untuk mengerjakan. Penelitian ini bertujuan untuk mengembangkan instrumen pengukuran kompleksitas soal kontekstual matematika. Metode penelitian yang digunakan adalah penelitian perancangan dan pengembangan. Subjek penelitian adalah beberapa mahasiswa calon guru matematika semester tujuh dan tujuh siswa kelas X. Instrumen telah divalidasi oleh pakar untuk memperoleh umpan balik dalam penyempurnaannya. Ujicoba diawali dengan meminta 8 mahasiswa calon guru matematika semester tujuh mengisi instrumen pengukuran kompleksitas soal kontekstual matematika, kemudian meminta ketujuh siswa kelas X mengerjakan soal yang diberikan. Dari hasil ujicoba penggunaan instrumen terhadap subjek penelitian diperoleh hasil bahwa instrumen dapat digunakan dengan baik dan dapat memberikan pengukuran yang baik akan kemampuan pemodelan matematis mahasiswa pendidikan matematika. Hasil penelitian menunjukkan bahwa telah berhasil dirancang dan disusun instrumen pengukuran kompleksitas masalah kontekstual matematika.
\end{abstract}

Kata-kata kunci: Pengembangan Instrumen; Kompleksitas Soal; Kontekstual.

Universitas Sanata Dharma

Email: Chatarinacitra05@gmail.com
C2017 Universitas Islam Negeri Walisongo $\mid 99$ ISSN: 2088-7868, e-ISSN 2502-5708 


\section{PENDAHULUAN}

Penerapan dan memodelkan masalah matematika melibatkan konteks masalah, contoh, dan tafsiran dalam proses mencari solusi. Berdasarkan artikel rujukan yang berjudul "Towards Constructing a Measure of the Complexity of Application Tasks" dikembangkanlah instrumen pengukuran kompleksitas soal kontekstual matematika. Kompleksitas soal-soal kontekstual matematika yang ada di Indonesia sampai saat ini belum ada instrumen pengukurannya. Kompleksitas sebuah soal kontekstual perlu dilakukan pengukuran agar dapat lebih tepat dalam penggunaannya, seperti waktu yang dibutuhkan untuk mengerjakan soal tersebut dan ketercapaian kompetensi.

Penelitian dilakukan di suatu SMA yang berada di Yogyakarta. Masalah penelitian adalah bagaimanakah pengembangan instrumen pengukuran kompleksitas suatu soal kontekstual matematika dan instrumen yang seperti apakah yang dapat mengukur kompleksitas suatu soal kontekstual matematika. Tujuan dari penelitian ini adalah untuk mengetahui proses pengembangan instrumen pengukuran kompleksitas suatu soal kontekstual matematika dan menemukan instrumen yang dapat mengukur kompleksitas suatu soal kontekstual matematika.

\section{METODE PENELITIAN}

Penelitian dilakukan di suatu SMA yang berada di Yogyakarta. Subjek penelitian adalah tujuh siswa SMA kelas $\mathrm{X}$ dan beberapa mahasiswa calon guru matematika semester tujuh. Jenis penelitian yang digunakan adalah yaitu penelitian penemuan dan pengembangan. Pengambilan data penelitian dilaksanakan pada tanggal 15 Oktober 2016.

Menurut Sugiyono (2011:407) mengatakan bahwa metode penemuan dan pengembangan atau dalam bahasa Inggrisnya Research and Development adalah metode penelitian yang digunakan untuk menghasilkan produk tertentu, dan menguji keefektifan produk tersebut. Tahap-tahap penemuan dan pengembangan telah dimodifikasi oleh Sukmadinata dkk sehingga terdiri atas tiga tahap yaitu 1) studi pendahuluan, 2) pengembangan model, dan 3) uji model. Studi pendahuluan meliputi tiga tahap yaitu 1) studi kepustakaan untuk mempelajari konsep-konsep atau teori-teori yang berkenaan dengan pengembangan instrumen pengukuran kompleksitas soal kontekstual, 2) survei lapangan, 3) penyusunan poduk awal atau draf model yang berupa soal-soal kontekstual dan instrumen untuk mengukur kompleksitas soal kontekstual. 
Pengembangan model diawali dengan meminta pakar untuk melakukan revisi dan memberikan masukan terhadap soal-soal kontekstual yang akan diberikan kepada siswa SMA kelas X dan instrumen untuk mengukur kompleksitas soal kontekstual. Berdasarkan masukan yang diberikan oleh pakar maka instrumen direvisi oleh peneliti dan instrumen yang sudah disempurnakan akan digandakan sesuai dengan kebutuhan.

Uji model dilakukan pada skala terbatas dan pada skala luas. Ujicoba skala terbatas melibatkan dua orang mahasiswa calon guru matematika semester tujuh yang diminta untuk mengerjakan soal-soal kontekstual. Hasil ujicoba skala terbatas kemudian direvisi untuk mendapatkan instrumen yang lebih valid yang kemudian diujicobakan pada tujuh siswa SMA kelas X.

\section{HASIL DAN PEMBAHASAN}

Penelitian dimulai dengan memberikan soal yang akan diujicobakan pada siswa SMA kelas X dan instrumen yang sudah divalidasi oleh pakar diberikan kepada beberapa mahasiswa calon guru matematika semester tujuh. Mereka diminta untuk mengisi instrumen pengukuran kompleksitas soal kontekstual matematika. Dalam mengisi instrumen tersebut, para mahasiswa calon guru matematika yang kini sudah memasuki semester tujuh harus memposisikan dirinya sebagai siswa kelas $\mathrm{X}$ yang seandainya diminta untuk mengerjakan soal-soal tersebut.

Peneliti mengembangkan instrumen dengan memperhatikan enam komponen penting yang peneliti yakini dapat mengukur kompleksitas suatu soal kontekstual matematika yaitu kompleksitas konseptual, kompleksitas matematika, kompleksitas linguistik, kompleksitas intelektual, kompleksitas representasional, dan kompleksitas kontekstual. Enam komponen penting tersebut masing-masing memiliki subkomponen yang peneliti pilih dengan mempertimbangkan bahwa subkomponen tersebut familiar atau masalah yang sering dijumpai ketika mengerjakan soal. Gambar 1 dan 2 adalah instrumen yang digunakan untuk mengukur kompleksitas soal kontekstual matematika. 


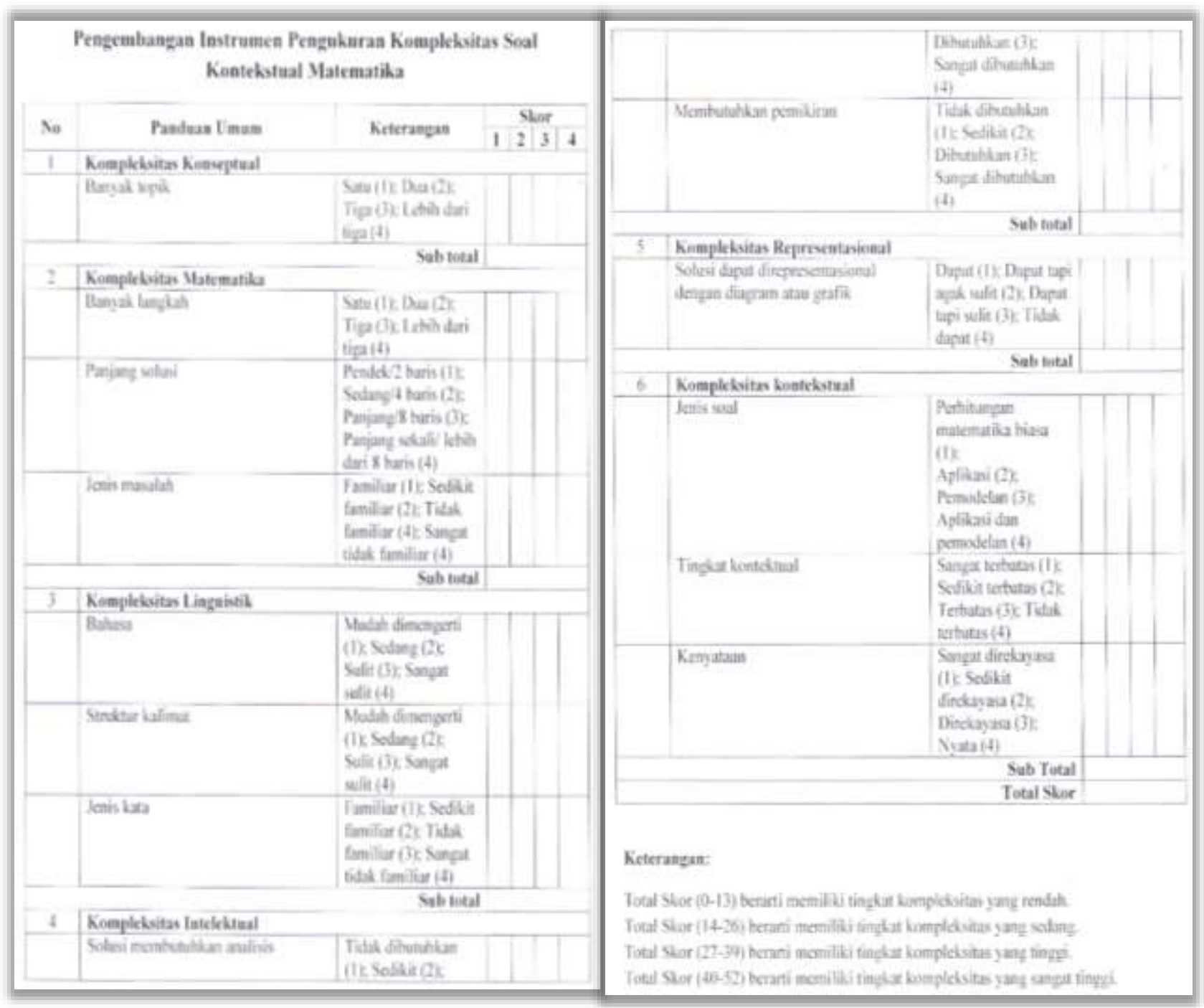

Gambar 1. Instrumen Pengukuran Kompleksitas Soal Kontekstual Matematika

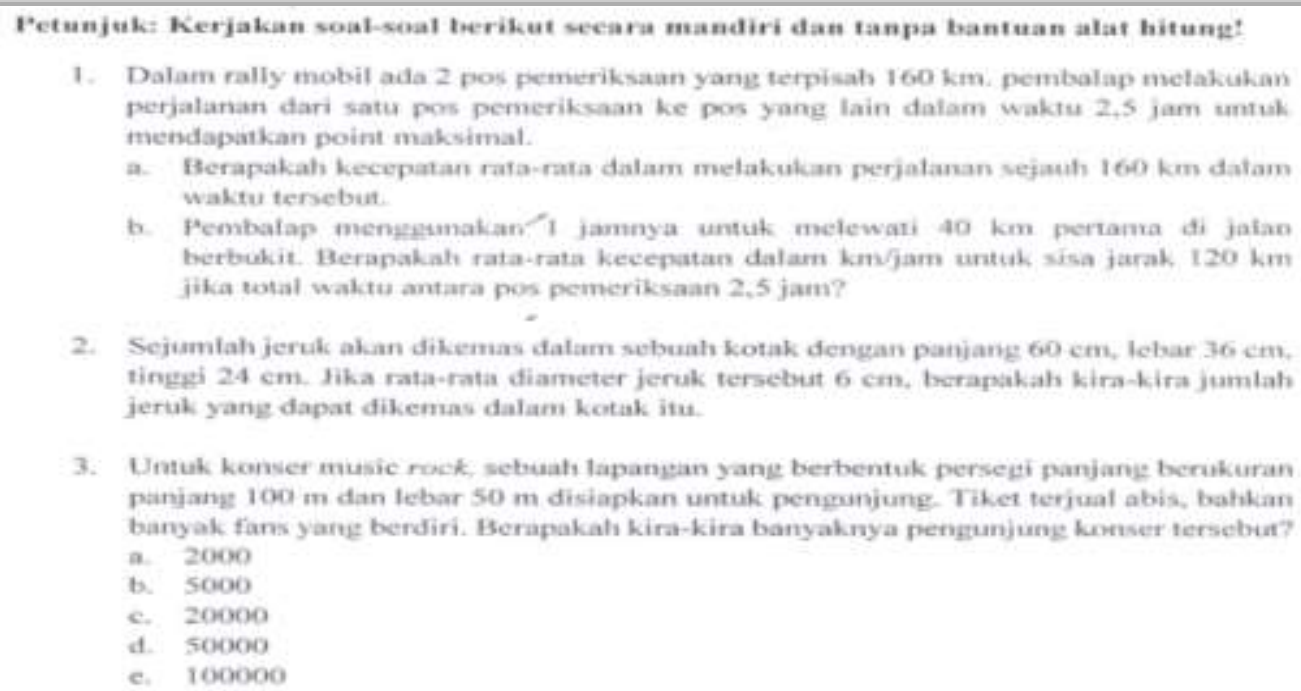

1. Dalam rally mobil ada 2 pos pemeriksaan yane terpisab $160 \mathrm{~km}$. pembalap melakukan perjalanan dari satu poss perneriksaan ke pos yane lain dalam waktu 2.5 jam untuk. mendapatkan point maksimal.

a. Berapakah kecepatan rafa-rata dalam melakukan perjatanan sejauh $160 \mathrm{~km}$ datam waktu tersebut.

b. Pembalap menygumakan /1 jammya untuk melewani $40 \mathrm{~km}$ pertama di jalas berbukit. Berapakah rata-rata kecepatan dalarn km/jam uratuk sisa jarak, $120 \mathrm{~km}$ jika total waktu antara pos pemeriksaan 2,5 jam?

2. Sejumlah jeruk akan dikemas datam subuah kotak dengan panjang $60 \mathrm{~cm}$, lebar $36 \mathrm{~cm}$. tinggi $24 \mathrm{~cm}$. Jika rata-rata diarmeter jeruk tersebut $6 \mathrm{~cm}$, berapakah kira-kira jumlah jeruk yang dapat dikemas dalam kotak itu.

3. Untuk konser music rock, sebuat, lapanjan yane berbentuk persejti panjanj berikuran panjany $100 \mathrm{~m}$ dan lebar $50 \mathrm{~m}$ disiapkan untuk penpanjung. Tiket terjuat abis, bahkan banyak fans yartg berdiri. Berapakati kira-kira banyaknya pengunjung konser tersebut? a. 2000

b. 5000

c. 20000

d. 50000

c. 100000

Gambar 2. Soal Kontekstual Matematika 
Tabel 1. adalah hasil instrumen pengukuran kompleksitas untuk soal nomor satu yang telah diisi oleh delapan mahasiswa calon guru matematika semester tujuh.

Tabel 1. Hasil Pengukuran Kompleksitas Soal Kontekstual Untuk Nomor Satu

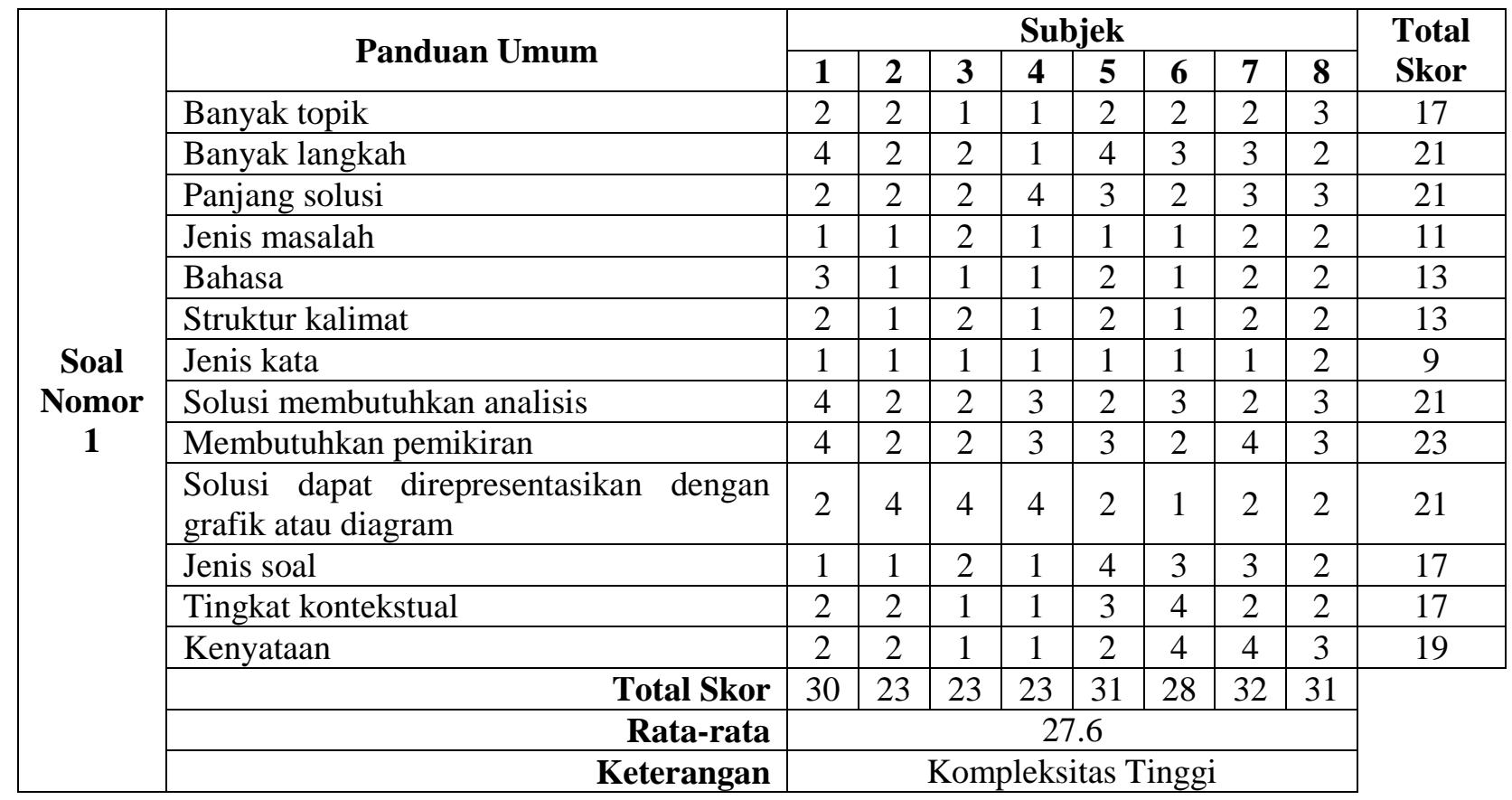

Berdasarkan hasil pengukuran kompleksitas soal kontekstual untuk soal nomor satu yang sudah diisi oleh delapan mahasiswa calon guru matematika semester tujuh berdasarkan instrumen yang ada, peneliti melakukan perhitungan dan berdasarkan kriteria yang ada didapat bahwa soal nomor satu memiliki tingkat kompleksitas yang tinggi karena memiliki rata-rata 27.6. Mahasiswa calon guru matematika semester tujuh memprediksi jika siswa SMA kelas X diberikan soal tersebut akan mempediksi sedikit kesulitan dalam hal memikirkan apa yang diinginkan oleh soal tersebut karena dalam menyelesaikan soal tersebut diperlukan analisis. Mereka juga memprediksi bahwa siswa akan menyelesaikan soal tersebut dengan berbagai macam cara dan menggunakan langkah yang cukup panjang.

Instrumen pengukuran soal kontekstual yang sudah diisi oleh delapan mahasiswa akan disinkronkan dengan hasil pekerjaan siswa. Apakah benar siswa cukup mengalami kesulitan dalam mengerjakan soal tersebut atau tidak dan apakah benar siswa menggunakan berbagai macam cara serta langkah penyelesaian yang cuku panjang. Gambar 3. adalah hasil pekerjaan siswa untuk soal nomor satu. 

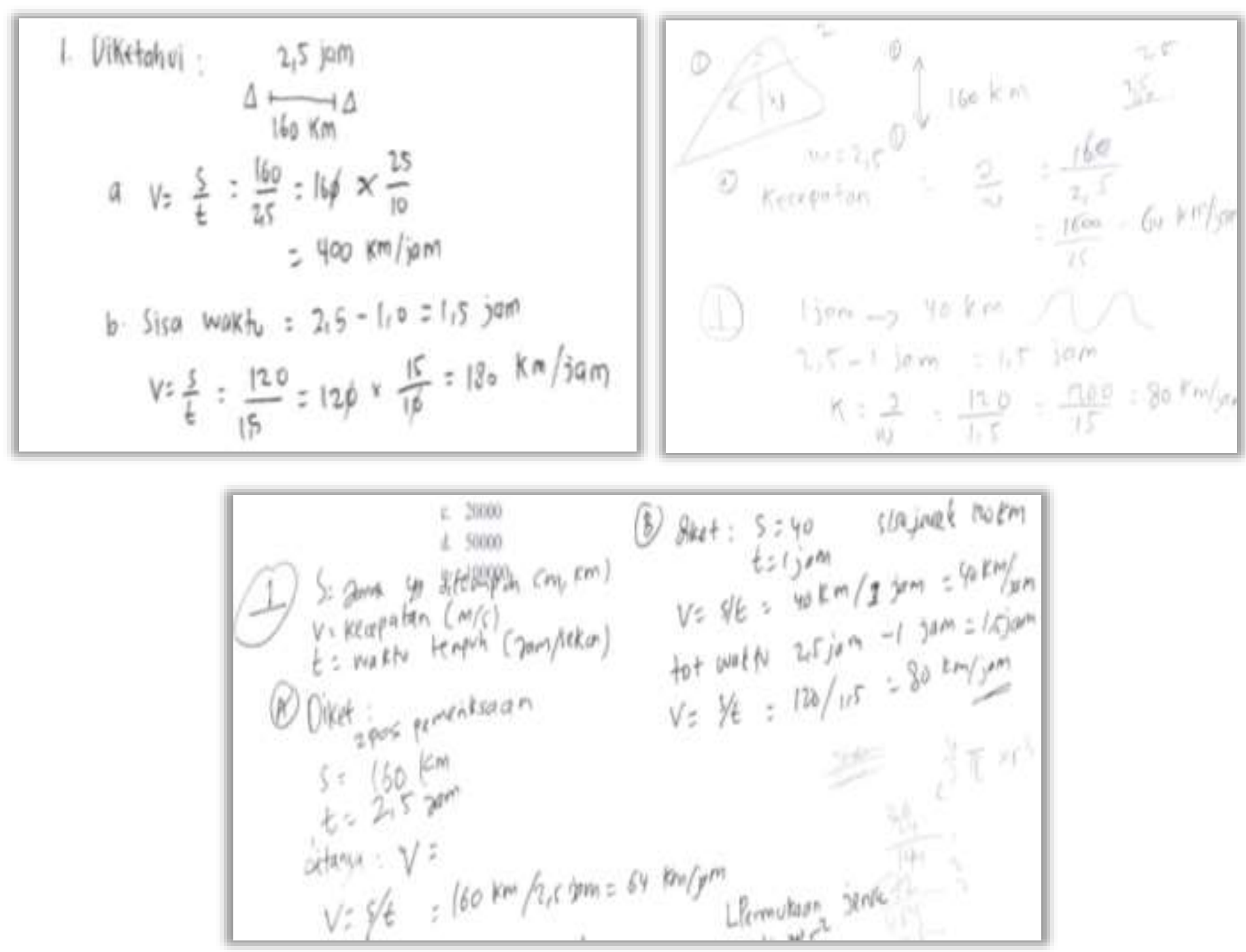

Gambar 3. Contoh Hasil Pekerjaan Siswa Untuk Soal Nomor Satu

Dari tujuh orang siswa SMA kelas X yang diminta untuk mengerjakan soal nomor satu, terdapat empat orang siswa yang menjawab soal tersebut dengan benar. Untuk tiga orang siswa yang lain, satu orang siswa mengalami kesalahan ketika menghitung karena kurangnya ketelitian dan dua orang siswa yang lainnya tidak memahami apa yang diinginkan oleh soal tersebut.

Berdasarkan hasil instrumen pengukuran kompleksitas untuk soal nomor satu yang telah diisi oleh delapan mahasiswa calon guru matematika semester tujuh dan hasil pekerjaan siswa untuk soal nomor satu, peneliti mengambil kesimpulan bahwa benar siswa mengalami sedikit kesulitan dalam memahami apa yang diinginkan oleh soal tetapi semua siswa menggunakan cara yang sama dengan langkah pengerjaan yang tidak terlalu panjang. 
Tabel 2 adalah hasil instrumen pengukuran kompleksitas untuk soal nomor dua yang telah diisi oleh delapan mahasiswa calon guru matematika semester tujuh.

\begin{tabular}{|c|c|c|c|c|c|c|c|c|c|c|}
\hline \multirow{18}{*}{$\begin{array}{c}\text { Soal } \\
\text { Nomor } \\
\quad 2\end{array}$} & \multirow{2}{*}{ Panduan Umum } & \multicolumn{8}{|c|}{ Subjek } & \multirow{2}{*}{$\begin{array}{l}\text { Total } \\
\text { Skor }\end{array}$} \\
\hline & & 1 & 2 & 3 & 4 & 5 & 6 & 7 & 8 & \\
\hline & Banyak topic & 2 & 4 & 2 & 2 & 1 & 1 & 2 & 2 & 16 \\
\hline & Banyak langkah & 3 & 3 & 2 & 2 & 4 & 2 & 1 & 2 & 19 \\
\hline & Panjang solusi & 3 & 3 & 1 & 2 & 3 & 2 & 2 & 2 & 18 \\
\hline & Jenis masalah & 1 & 1 & 1 & 2 & 1 & 2 & 1 & 1 & 10 \\
\hline & Bahasa & 1 & 2 & 1 & 2 & 1 & 2 & 1 & 1 & 11 \\
\hline & Struktur kalimat & 1 & 2 & 1 & 2 & 1 & 2 & 2 & 1 & 12 \\
\hline & Jenis kata & 1 & 2 & 1 & 3 & 1 & 1 & 1 & 1 & 11 \\
\hline & Solusi membutuhkan analisis & 2 & 2 & 2 & 2 & 2 & 3 & 3 & 2 & 18 \\
\hline & Membutuhkan pemikiran & 3 & 3 & 2 & 4 & 3 & 3 & 4 & 2 & 24 \\
\hline & $\begin{array}{l}\text { Solusi dapat direpresentasikan dengan } \\
\text { grafik atau diagram }\end{array}$ & 4 & 2 & 4 & 1 & 4 & 4 & 4 & 1 & 24 \\
\hline & Jenis soal & 2 & 2 & 2 & 2 & 4 & 2 & 3 & 2 & 19 \\
\hline & Tingkat kontekstual & 4 & 2 & 1 & 4 & 2 & 3 & 3 & 2 & 21 \\
\hline & Kenyataan & 4 & 2 & 2 & 3 & 2 & 3 & 4 & 2 & 22 \\
\hline & Total Skor & 31 & 30 & 22 & 31 & 29 & 31 & 31 & 21 & \\
\hline & Rata-rata & & & & & & & & & \\
\hline & Keterangan & & & Kom & leks & $\tan 7$ & ingg & & & \\
\hline
\end{tabular}

Tabel 2. Hasil Pengukuran Kompleksitas Soal Kontekstual Untuk Nomor Dua

Seperti pada pengukuran kompleksitas soal kontekstual untuk nomor satu, peneliti juga melakukan perhitungan setelah delapan mahasiswa calon guru matematika semester tujuh mengisi instrumen untuk mengukur tingkat kompleksitas untuk soal nomor dua. Berdasarkan rata-rata dan kriteria yang ada, didapatkan bahwa untuk soal nomor dua memiliki tingkat kompleksitas yang tinggi tetapi lebih tinggi daripada soal nomor satu. Mahasiswa calon guru matematika semester tujuh memprediksi jika siswa SMA kelas X diberikan soal tersebut akan mengalami kesulitan dalam hal memikirkan apa yang diinginkan oleh soal tersebut karena dalam menyelesaikan soal tersebut. Mereka juga memprediksi bahwa siswa akan kesulitan jika solusi dari soal tersebut direpresentasikan dengan diagram atau grafik.

Instrumen pengukuran soal kontekstual yang sudah diisi oleh delapan mahasiswa akan disinkronkan dengan hasil pekerjaan siswa. Apakah benar siswa cukup mengalami kesulitan dalam mengerjakan soal tersebut atau tidak. Gambar 4. adalah hasil pekerjaan siswa untuk soal nomor dua. 


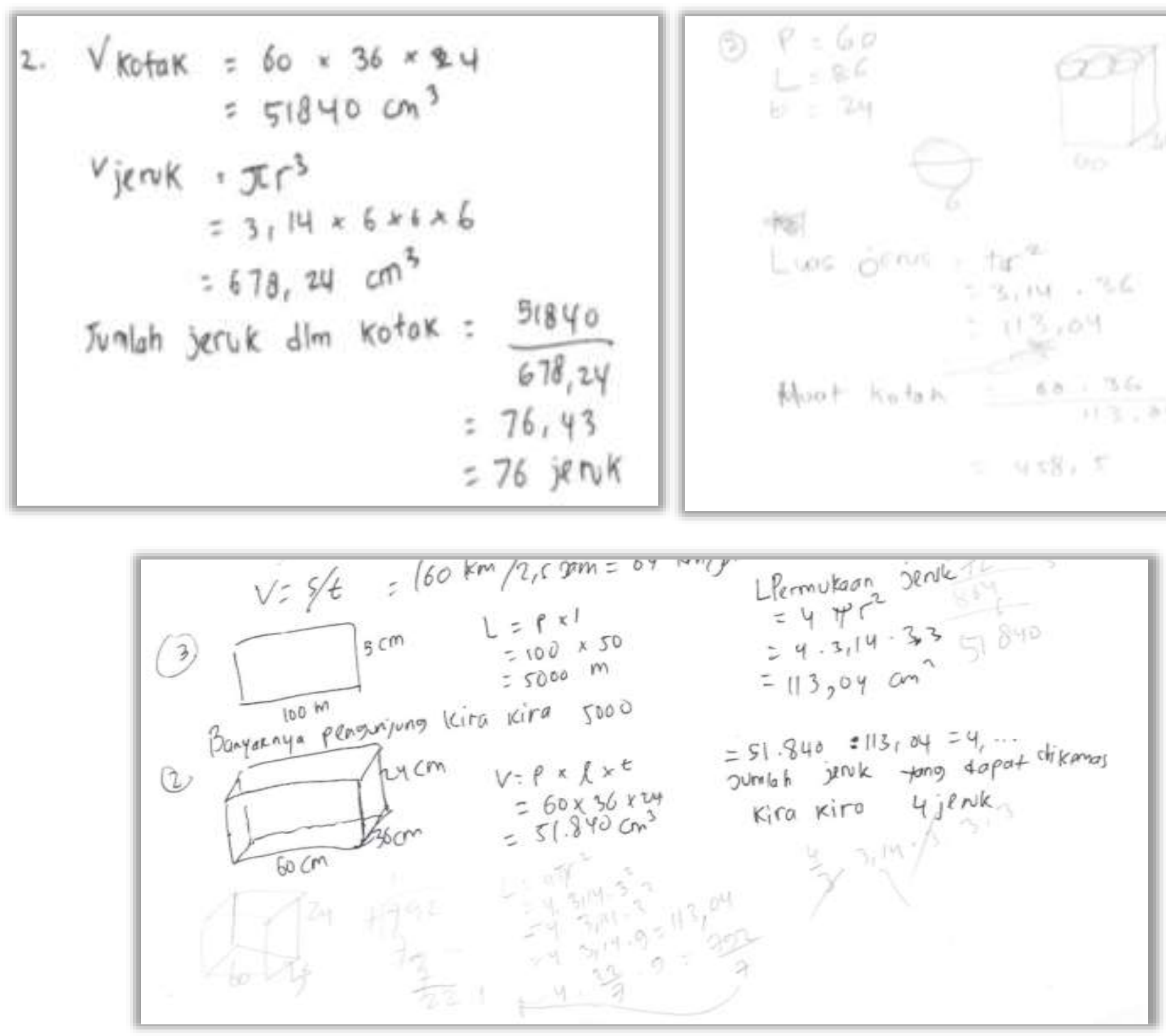

Gambar 4. Contoh Hasil Pekerjaan Siswa Untuk Soal Nomor Dua

Dari tujuh orang siswa SMA kelas X yang diminta untuk mengerjakan soal nomor dua, tidak ada siswa yang menjawab soal tersebut dengan benar. Semua siswa mengerjakan soal tersebut dengan cara mencari volume kotak lalu dibagi dengan volume jeruk. Berdasarkan hasil instrumen pengukuran kompleksitas untuk soal nomor dua yang telah diisi oleh delapan mahasiswa calon guru matematika semester tujuh dan hasil pekerjaan siswa untuk soal nomor dua, peneliti mengambil kesimpulan bahwa siswa sudah memahami apa yang diinginkan oleh soal tersebut hanya saja siswa kurang berpikir lebih dalam untuk mencari cara yang lebih mudah untuk menyelesaikan soal tersebut dan 
tidak ada siswa yang menyeleaikan soal tersebut dengan menggunakan grafik atau diagram.

Tabel 3. adalah hasil instrumen pengukuran kompleksitas untuk soal nomor dua yang telah diisi oleh delapan mahasiswa calon guru matematika semester tujuh.

Tabel 3. Hasil Pengukuran Kompleksitas Soal Kontekstual Untuk Nomor Tiga

\begin{tabular}{|c|c|c|c|c|c|c|c|c|c|c|}
\hline & & & & & & & & & & Total \\
\hline & Panduan Umum & 1 & 2 & 3 & 4 & 5 & 6 & 7 & 8 & Skor \\
\hline & Banyak topik & 2 & 1 & 1 & 2 & 1 & 1 & 1 & 3 & 12 \\
\hline & Banyak langkah & 4 & 2 & 2 & 4 & 2 & 2 & 1 & 3 & 20 \\
\hline & Panjang solusi & 3 & 2 & 2 & 4 & 2 & 1 & 2 & 2 & 18 \\
\hline & Jenis masalah & 1 & 2 & 2 & 1 & 1 & 3 & 1 & 1 & 12 \\
\hline & Bahasa & 1 & 1 & 1 & 4 & 1 & 3 & 2 & 1 & 14 \\
\hline & Struktur kalimat & 1 & 1 & 2 & 2 & 1 & 2 & 2 & 2 & 13 \\
\hline Soal & Jenis kata & 1 & 1 & 1 & 4 & 1 & 2 & 2 & 2 & 14 \\
\hline Nomor & Solusi membutuhkan analisis & 3 & 2 & 2 & 4 & 2 & 3 & 3 & 3 & 22 \\
\hline 3 & Membutuhkan pemikiran & 3 & 2 & 2 & 4 & 3 & 2 & 4 & 3 & 23 \\
\hline & $\begin{array}{l}\text { Solusi dapat direpresentasikan dengan } \\
\text { grafik atau diagram }\end{array}$ & 4 & 4 & 4 & 2 & 4 & 1 & 4 & 2 & 25 \\
\hline & Jenis soal & 2 & 2 & 2 & 4 & 4 & 3 & 3 & 2 & 22 \\
\hline & Tingkat kontekstual & 3 & 1 & 1 & 1 & 2 & 2 & 2 & 2 & 14 \\
\hline & Kenyataan & 4 & 2 & 1 & 1 & 2 & 2 & 3 & 3 & 18 \\
\hline & Total Skor & 32 & 23 & 23 & 37 & 26 & 27 & 30 & 29 & \\
\hline & Rata-rata & & & & & & & & & \\
\hline & Keterangan & & & Kom & lek & tas & ingg & & & \\
\hline
\end{tabular}

Setelah delapan mahasiswa calon guru matematika semester tujuh mengisi instrumen untuk mengukur tingkat kompleksitas untuk soal nomor tiga, dilakukanlah perhitungan. Berdasarkan rata-rata dan kriteria yang ada didapatkan bahwa untuk soal nomor tiga memiliki tingkat kompleksitas yang tinggi tetapi lebih tinggi daripada soal nomor satu dan nomor dua. Sama seperti pada soal nomor satu dan dua, mahasiswa calon guru matematika semester tujuh memprediksi jika siswa SMA kelas $\mathrm{X}$ diberikan soal tersebut akan mengalami kesulitan untuk menyelesaikan soal tersebut karena dalam menyelesaikan soal nomor tiga diperlukan analisis dan pemikiran yang dalam serta jenis soal termasuk dalam soal pemodelan. Mereka juga memprediksi bahwa siswa mungkin saja akan salah dalam mengartikan apa yang diinginkan oleh soal tersebut dan kesulitan jika solusi dari soal tersebut direpresentasikan dengan diagram atau grafik.

Instrumen pengukuran soal kontekstual yang sudah diisi oleh delapan mahasiswa akan disinkronkan dengan hasil pekerjaan siswa. Apakah benar siswa cukup mengalami kesulitan dalam mengerjakan soal tersebut atau tidak. Berikut adalah hasil pekerjaan 
siswa untuk soal nomor tiga.
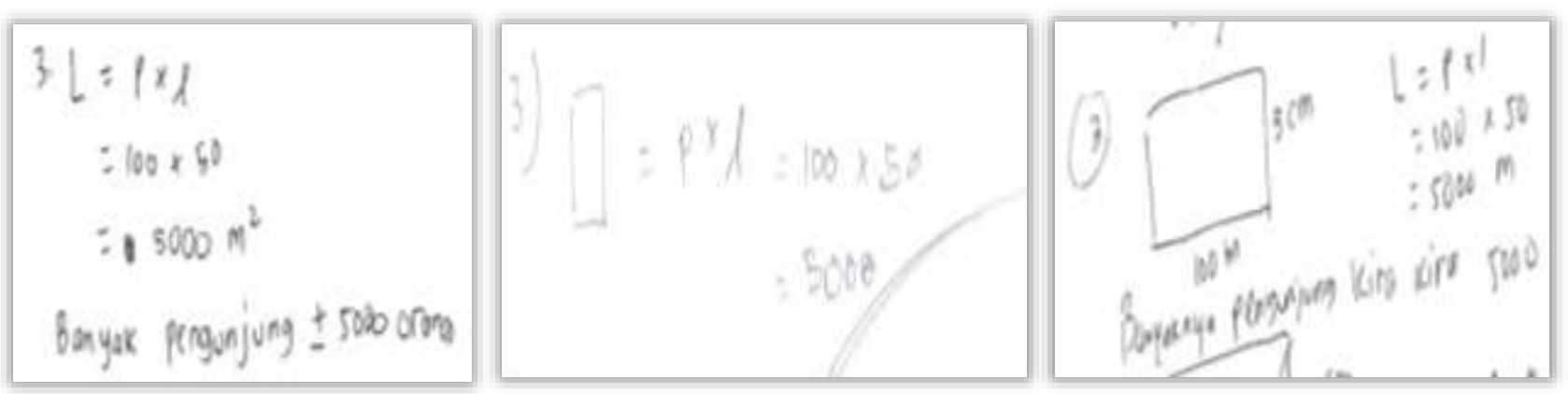

Gambar 5. Contoh Hasil Pekerjaan Siswa Untuk Soal Nomor Tiga

Tidak ada siswa yang menjawab soal nomor tiga dengan benar. Ketujuh siswa mengerjakan soal nomor tiga dengan cara mencari luas lapangan yaitu panjang lapangan dikalikan dengan lebar lapangan sehingga didapat $5000 \mathrm{~m}^{2}$ dan semua siswa langsung menyimpulkan bahwa kira-kira banyaknya pengunjung konser sebanyak 5000 orang. Mereka tidak memikirkan jika kira-kira pengunjung konsernya sebanyak 5000 orang berarti setiap orang mendapat $1 \mathrm{~m}^{2}$. Seharusnya $1 \mathrm{~m}^{2}$ dapat diisi oleh 3-4 orang yang memiliki berat badan standar.

Berdasarkan hasil instrumen pengukuran kompleksitas untuk soal nomor dua yang telah diisi oleh delapan mahasiswa calon guru matematika semester tujuh dan hasil pekerjaan siswa untuk soal nomor tiga, peneliti mengambil kesimpulan bahwa siswa mengalami kesulitan untuk menyelesaikan soal tersebut karena diperlukan analisis dan pemikiran yang dalam. Siswa juga salah dalam mengartikan apa yang diinginkan oleh soal tersebut dan kesulitan jika solusi dari soal tersebut direpresentasikan dengan diagram atau grafik.

\section{SIMPULAN DAN SARAN}

Pengembangan instrumen pengukuran kompleksitas soal kontekstual matematika dilakukan berdasarkan studi literatur dan penelitian yang relevan. Sebelum instrumen yang dikembangkan untuk mengukur kompleksitas soal kontekstual matematika dibagikan kepada mahasiswa calon guru matematika semester tujuh, instrumen tersebut divalidasi terlebih dahulu oleh pakar.

Berdasarkan penelitian didapatkan hasil bahwa terdapat kesesuaian antara prediksi berdasarkan instrumen yang diisi oleh beberapa mahasiswa calon guru matematika 
semester tujuh dengan hasil pekerjaan siswa sehingga dapat disimpulkan bahwa instrumen yang telah dikembangkan dapat digunakan dengan baik untuk mengukur kompleksitas soal kontekstual matematika. Jika guru memberikan ketiga soal kontekstual tersebut secara terpisah, maka soal nomor tiga harus diberikan waktu pengerjaan lebih lama daripada soal nomor satu dan dua karena soal tersebut membutuhkan analisis dan pemikiran yang dalam untuk menentukan penyelesaiannya.

\section{DAFTAR RUJUKAN}

Lakadewi, Alfina Novita. (2014). Profil Kemampuan Siswa SMA Pangudi Luhur Van Lith Kelas X dalam Menyelesaikan Soal-soal Timss Grade 8 Tipe Penalaran. Skripsi. Universitas Sanata Dharma Yogyakarta.

Noordyah. (2011). Langkah-langkah Penelitian dan Pengembangan. (Artikel Online) Didapat dari https://noordyah.wordpress.com/tugas-kuliah/langkah-langkahpenelitian-dan-pengembangan/ (Diakses tanggal 27 Oktober 2016).

Setiawan, Harianto dkk. (2014). Soal Matematika dalam pisa Kaitannya dengan Literasi Matematika dan Keterampilan Berpikir Tingkat Tinggi. Prosiding Seminar Nasional Matematika, Universitas Jember, 19 November 2014. (Online) Didapat dari http://jurnal.unej.ac.id/index.php/psmp/article/viewFile/955/758 (Diakses pada 6 Oktober 2016)

Stillman, Gloria dan Peter Galbraith. (2003). Towards Constructing a Measure of the Complexity of Application Tasks. Mathematical Modeling: A Way of Life, no. 16: pp. 179-188. Horwood Publishing Chichster.

Sugiyono. (2010). Metode Penelitian Pendidikan: Pendekatan Kuantitatif, Kualitatif, dan $R \& D$. Bandung: Alfabeta. 